\section{$\underset{\text { hommes }}{\text { \& migrations }}$}

\section{Hommes \& migrations}

Revue française de référence sur les dynamiques

migratoires

1277 | 2009

France - Allemagne

\title{
Habib Selmi - La Nuit de l'étranger
}

Éd. Actes Sud, 2008, 190 pages, 19 euros

\section{Mustapha Harzoune}

\section{(2) OpenEdition}

\section{Journals}

\section{Édition électronique}

URL : http://journals.openedition.org/hommesmigrations/194

DOI : 10.4000/hommesmigrations. 194

ISSN : 2262-3353

Éditeur

Musée national de l'histoire de l'immigration

\section{Édition imprimée}

Date de publication : 1 janvier 2009

Pagination : 147

ISSN : 1142-852X

\section{Référence électronique}

Mustapha Harzoune, « Habib Selmi - La Nuit de l'étranger », Hommes \& migrations [En ligne], 1277|

2009, mis en ligne le 29 mai 2013, consulté le 22 septembre 2020. URL : http://

journals.openedition.org/hommesmigrations/194; DOI : https://doi.org/10.4000/hommesmigrations. 194

Ce document a été généré automatiquement le 22 septembre 2020.

Tous droits réservés 


\title{
Habib Selmi - La Nuit de l'étranger
}

\author{
Éd. Actes Sud, 2008, 190 pages, 19 euros
}

Mustapha Harzoune

\section{RÉFÉRENCE}

Habib Selmi - La Nuit de l'étranger, roman traduit de l'arabe (Tunisie) par Évelyne Larguèche et François Neyrod, éd. Actes Sud, 2008, 190 pages, 19 euros.

1 C'est la nuit. Une nuit d'insomnie dans une turne où le grabat voisine avec un lavabo et un petit réchaud pour la tambouille et le café quotidiens. Le tout-en-un du parfait exilé. L'homme est allongé. Seul, il consulte son vieux répertoire téléphonique. Qui appeler? Avec qui partager sa solitude, tisser un lien d'humanité ? Il tourne les pages du calepin. En vain. Restent des noms et autant de destins. Destins d'immigrés, comme le sien. Il y a Adel Talibi, Hamouda Achhab, celui qu'on appelle le Hadj depuis son pèlerinage, et Souad Gharsallah. Le narrateur, un jeune tunisien, se souvient de chacun.

Hamouda et sa femme, la belle et forte Hadhria, sont venus en France pour soigner les spermatozoïdes "fainéants" de monsieur. Ils pensaient bien repartir en Tunisie une fois qu'Hamouda aurait fécondé son épouse. Ils eurent deux enfants, mais, au soir de leur vie, ils se retrouvent seuls, dans le "trou", un petit appartement dans un foyer de la Sonacotra, lui, supportant la honte du chômage et le mépris des secrétaires des boîtes d'intérim.

Souad, rebelle et libre, est responsable de l'association des Tunisiennes émigrées. Sa féminité terrorise les hommes qui le lui font payer cher. Tous les hommes, y compris le premier, son père, qui pourtant la chérissait. Souad, l'amante du narrateur, incarne le refus des traditions et autres croyances qui réduisent chaque femme à une membrane impérativement intacte jusqu'à la défloraison nuptiale, quasi publique (voir la très forte scène de la nuit de noces de la tante de Souad). Ses silences masquent parfois le prix de sa liberté. Adel est le fils du pauvre. Celui qui veut réussir, faire des études pour devenir quelqu'un et permettre à son père de recouvrer cette dignité dont la vie et la misère l'ont privé. "L'idée de revanche" a germé chez lui depuis le plus jeune âge. Peut- 
être depuis cette autre scène forte où le père offre à son fiston une paire de chaussures... trop petites.

4 Habib Selmi, sur un mode plus grave que son précédent roman (Les Amants de Baya, voir $H \& M n^{\circ} 1247$ janvier 2004), croise les récits pour dire à sa manière cette plus haute des solitudes que constitue l'exil. Dans La Nuit de l'étranger, l'exil est le temps du tourment, le "sentiment d'échec et d'incapacité", "les villes brumeuses et froides, les visages impénétrables, et les chambres grises", un "déchirement". Habib Selmi dit aussi l'amour qui, de la passion à la tendresse, unit Hamouda et Hadhria, la foi, sincère et sans prêchi-prêcha d'Adel, comme le refus d'Hamouda de céder aux démonstrations de religiosité et d'importance des pèlerins de retour de La Mecque.

Il y a bien l'entre-soi, ces cafés où se retrouvent les Tunisiens, le brassage d'hommes venus d'horizons différents réunis dans l'immigration, la solidarité du voisinage, l'entraide pour lire les courriers et remplir les paperasses de l'administration... Il n'empêche, les destins sont souvent contrariés, les espérances envolées. L'émigration n'est qu'une "illusion". 